https://doi.org/

УДК 553.495 (477)

\title{
Тищенко Ю.Є.
}

Тищенко Ю.Є. канд.. геол. н., с. н. с., ДУ «ГГНС НАН України», u-risk@ ukr.net

\section{МЕТОД ПРОСТОРОВОГО ВІДОБРАЖЕННЯ ПОЛІВ РОЗПОДІЛУ РАДІАЦІЙНИХ ПОКАЗНИКІВ НА ПРИКЛАДІ ОБРОБКИ РЕЗУЛЬТАТІВ ВИМІРЮВАНЬ НА ТЕРИТОРІЇ НОВОКОСТЯНТИНІВСБКОГО РОДОВИЩА УРАНУ}

Стаття присвячена питанню оптимізації прочесу та інтерпретації інформації, отриманої під час радіологічних вимірювань компонентів навколищнього середовища, на прикладі обробки даних досліджень, проведених на території Новокостянтинівського родовища урану та однойменної шахти. Аналітичне опрачювання масивів фактичних даних супроводжується їх просторовим відображенням за допомогою засобів комп'ютерного картування. Ефективність такого відображення залежить від надійності вибору критеріїв, за якими будуються просторові поля розподілу виміряних показників. У статті запропоновано підходи до просторового відображення результатів конкретних радіоекологічних моніторингових досліджень, які протягом трьох років виконуються Інститутом геохімії навколишнього середовища Національної академії наук України. 3 використанням фактичних даних, отриманих під час польових вишукувань, показано метод ранжування рядів виміряних показників, в основу якого покладено урахування апаратурної похибки приладу при виконанні того чи іншого інструментального вимірювання. Метод обробки інформації проілюстровано результатами побудови карт просторового розподілу виміряних показників щільності потоку (ексхалації) радону з трунту, отриманих під час останніх за часом польових робіт. На картах виділено поля розподілу «фонових» та аномально високих виміряних показників. Останні локалізовані у місиі дислокаиії видобувних потужностей шахти. Також простежується наявність аномальних зон у місиях залягання геологічних розломних структур та ймовірних зон розущільнення осадової товщі. Наведені результати просторового відображення порівнюються з аналогічними результатами картування фактичних даних попереднього року досліджень та результатами картування іншого показника радіологічних вимірювань - потужності еквівалентної дози гаммавипромінювання у навколишньому середовищі. Отримані результати показують, що описаний метод може бути застосований для надійного виділення аномальних зон розподілу виміряних показників радіоактивності та їх просторового відображення. Картування аномальних зон може бути використане при очінюванні радіоекологічної ситуачії на радіачійно забруднених територіях, зокрема - родовищах урану, а також, як опосередкований пошуковий критерій дистанційних досліджень. Також у статті наведено коротку геологічну характеристику Новокостянтинівського родовища урану, показані його геологічний план та розрізи.

Ключові слова: уран, родовище, радон, радіація, поля розподілу, картування

\section{Вступ}

ДУ «ГГНС НАН України» протягом кількох років проводить щорічні польові моніторингові дослідження, які полягають у натурному і камеральному вимірюванні ряду радіаційних показників на територіях кількох родовищ урану в Україні (як таких, що розробляються, так і тих, які можуть бути заплановані для розробки у майбутньому). Дані роботи виконуються у рамках державної тематики; їх результати відображені у багатьох наукових звітах та двох монографіях [1, 2].

Одним із важливих елементів зазначених досліджень $є$ просторове відображення їх результатів методом комп'ютерного картування. У цьому аспекті необхідно розробити надійні, прості і зрозумілі критерії виділення просторових зон аномального забруднення (більш високого, порівняно $з$ забрудненням прилягаючих територій, умовно - «фоновим» забрудненням).

У статті показано деякі підходи до аналітичного опрацювання матеріалу на прикладі обробки результатів досліджень, проведених на території Новокостянтинівського родовища урану.

Новокостянтинівське уранове родовище натрійуранової формації

Новокостянтинівське родовище (або рудне поле) розташоване в північній частині Новоукраїнського гранітного масиву поблизу контакту з гранітами рапаківі Корсунь-Новомиргородського плутону в Новокостянтинівській зоні розлому меридіонального напрямку [3-5]. На рисунках 1-3 показані геологічний план та розрізи території родовища.

Ізохронний вік новоукраїнських гранітів складає 2025-2040 млн. років [7, 8], рудних альбітитів Ново- 
костянтинівської зони - від 1800 до $1835 \pm$ 60 млн. років [3, 7].

Вміщуючими породами є крупнопорфіробластові граніти, окремими ділянками зустрічаються аплітопегматоїдні їх різновиди, а також останці біотитових та піроксен-амфіболових гнейсів. Головними мінералами урану є уранініт і бранерит.

У геоморфологічному відношенні рудне поле розташоване на схилі вододілу між верхів'ями річок Мала Вись та Велика Вись, що належать до басейну р. Південний Буг. Територія субгоризонтальна, розчленована ярами та балками (глибини врізу 20-50 м) рівнина $з$ максимальними абсолютними відмітками поверхні 220-230 м.

Сучасний рельєф ерозійно-акумулятивний 3 пологим нахилом у північному напрямку. Потужність оса- дової товщі, яка залягає на корі вивітрювання кристалічних порід докембрію, коливається в межах від 20 до 70 м. У рельєфі сучасної поверхні знайшли відображення позитивні вертикальні рухи земної кори, відображені також і на поверхні кристалічного фундаменту, зумовивши підвищену тріщинуватість кристалічних порід і сприятливі умови для гідравлічного зв'язку між різнорівневими горизонтами підземних вод.

У товщі осадових порід сформувалось 7 водоносних горизонтів (від алювіального до бучацького); найбільш продуктивний водоносний горизонт зосереджений у тріщинних зонах кори вивітрювання кристалічного фундаменту.
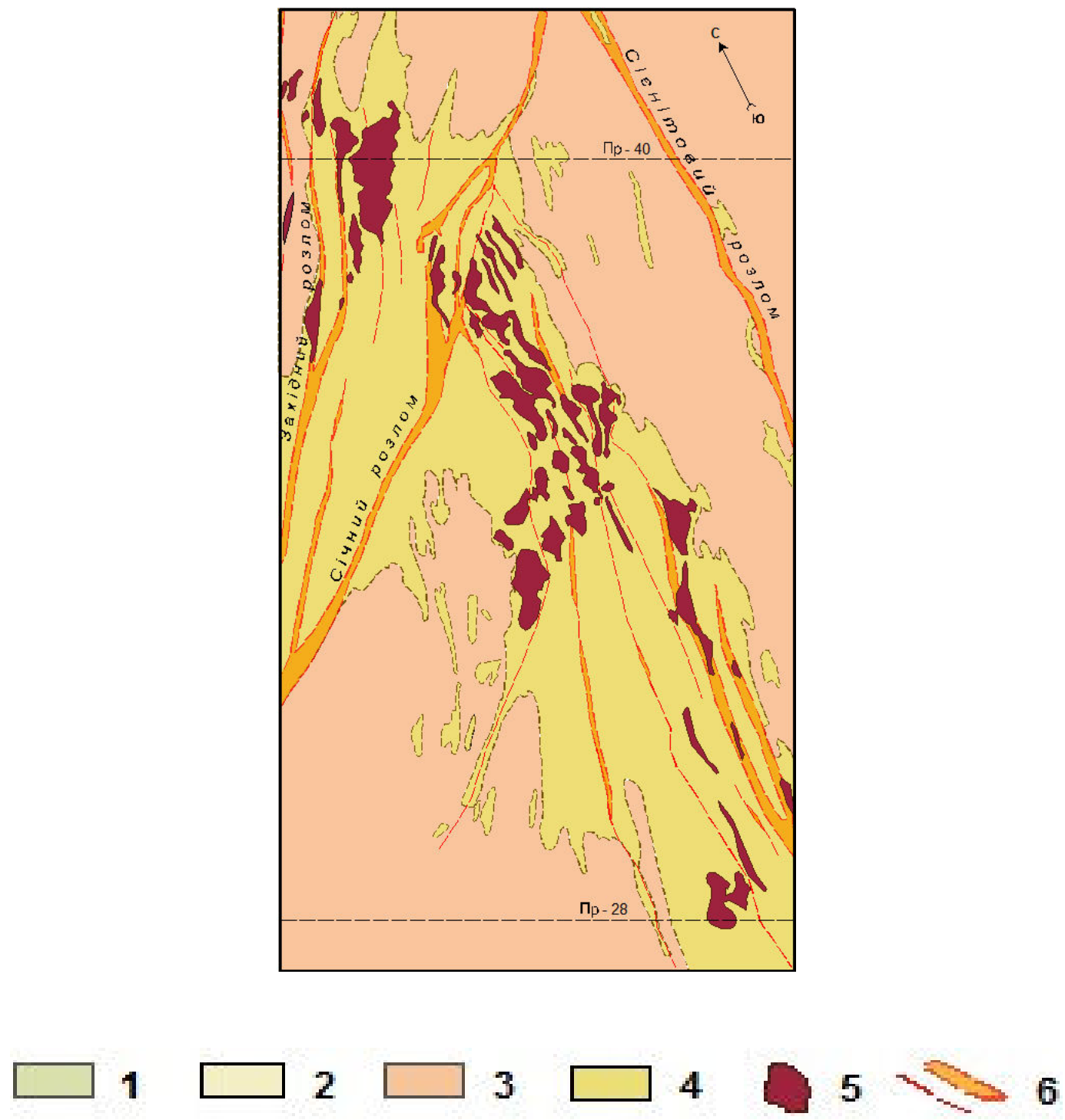

Рис. 1. Геологічний план Новокостянтинівського родовища урану за [6]. 1 - кайнозойські осадові породи; 2 - кора вивітрювання кристалічних порід; 3 - граніти новоукраїнського комплексу; 4 - альбітити та діафторовані сієнітоподібні породи; 5 тектонічні порушення; 6 - рудні зони.

Fig. 1. Geological plan of Novokostiantynivske uranium deposit [6] 


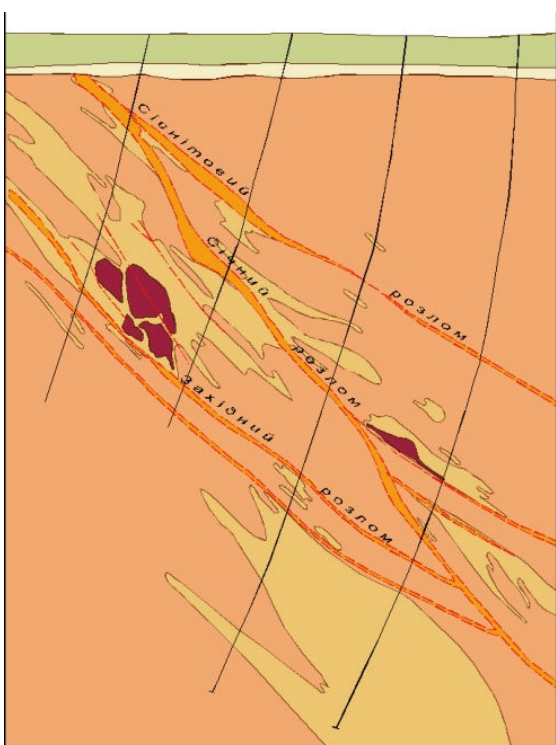

Рис. 2. Схематичний геологічний розріз Новокостянтинівського родовища урану по профілю 40 за [6].

Fig. 2. Geological section of Novokostiantynivske uranium deposit on profile 40 [6]

Метою досліджень $є$ розробка методу просторового виділення аномальних зон радіаційних забруднень на територіях проведених радіоекологічних вишукувань, які картуються 3 використанням сучасних програмних засобів.

\section{Виклад матеріалу досліджень}

Моніторингові радіологічні дослідження, які проводяться ДУ «ГГНС НАН України» на території Новокостянтинівського родовища, включають контроль наступних радіаційних параметрів навколишнього середовища: дозиметричні - польові вимірювання потужності експозиційної дози гаммавипромінювання (радіаційний фон); потужності еквівалентної дози (ПЕД) гамма-випромінювання; польові радіометричні вимірювання активності радону-222 - щільності потоку, або ексхалації (ЩПР) з грунту; лабораторні радіометричні вимірювання питомої інтегральної гамма-активності проб грунту; лабораторні радіометричні вимірювання альфа- та бета-активності для визначення мас-еквівалентного вмісту та радіоактивності проб грунту, приведеної до урану; лабораторні спектрометричні вимірювання радіонуклідів у пробах грунту. До комплексу польових робіт входять відбори проб грунтів (шпуровим методом до глибини 1 м) та природних вод (поверхневих і підземних) i геопозиційна прив'язка пунктів опробування та пробовідбору.

За результатами польових і лабораторних досліджень побудовано відповідні карти полів розподілу виміряних показників (із використанням програмних

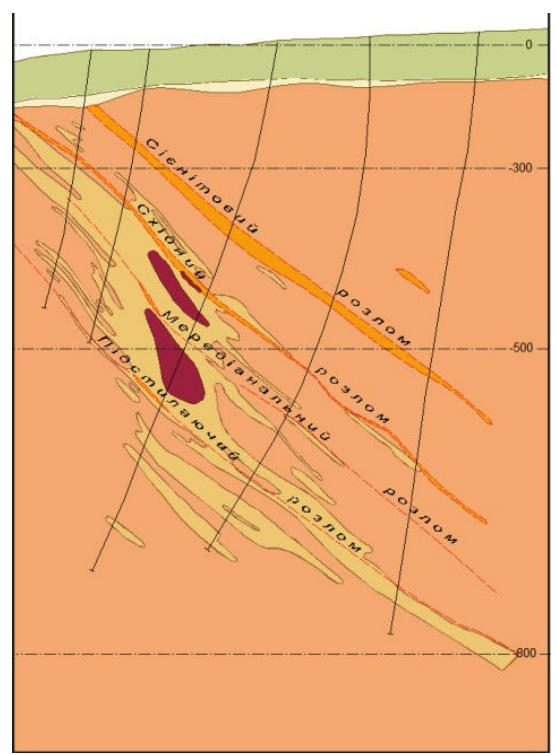

Рис. 3. Схематичний геологічний розріз Новокостянтинівського родовища урану по профілю 28 за [6].

Fig. 3. Geological section of Novokostiantynivske uranium deposit on profile 28 [6]

продуктів: ГІС-пакетів Mapinfo Professional 9.5 та ArcMap 10.3, а також Exel 2013 i Access 2007).

Одним із головних завдань досліджень $є$ виділення зон аномально високих виміряних показників радіоактивності. Покажемо метод такого виділення на прикладі обробки результатів вимірювання ЩПР у 2018 році.

Активність і щільність потоку з грунту радону залежить від двох взаємопов' язаних факторів: концентрації трансуранових радіоактивних елементів у гірських породах кристалічного фундаменту і осадовій товщі та інтенсивності його еманації. Інтенсивність еманації радону значно вища у тектонічно ослаблених зонах, на ділянках з тріщинуватим характером вміщуючих порід, у районах глибоких тектонічних порушень тощо, оскільки така геологічна будова полегшує вивільнення радону із гірських порід у приповерхневі шари. Саме такі геологічні умови сприятливі для уранового зруденіння [9].

Нижче (табл. 1) наведено статистичні показники вимірювань ЩПР на Новокостянтинівському родовищі.

Проілюструємо метод обробки результатів досліджень на прикладі побудови карт розподілу виміряних значень ЩПР за 2018 рік. У Табл. 2 наведено фактичні результати з координатною прив'язкою пунктів опробування.

Досліджувана територія у зоні впливу шахти Новокостянтинівська характеризується у цілому дуже високими показниками ексхалації радону з грунту. 
Таблиця 1. Основні статистичні дані щодо вимірювання ЩПР радону на території зони спостережень Новокостянтинівського родовища урану

Table 1. Main statistical data on radon flow measurement on the territory of the Novokostiantynivske uranium deposit monitoring zone

\begin{tabular}{|c|c|c|c|c|c|c|c|c|}
\hline \multirow{2}{*}{$\mathrm{N}$} & \multirow{2}{*}{ Показник } & \multirow{2}{*}{2016} & \multirow{2}{*}{2017} & \multirow{2}{*}{2018} & \multirow{2}{*}{ Середнє } & \multicolumn{3}{|c|}{ Відхилення від середнього } \\
\hline & & & & & & 2016 & 2017 & 2018 \\
\hline 1 & $\begin{array}{l}\text { Кількість пунктів опробування (ана- } \\
\text { лізів) }\end{array}$ & 17 & 16 & 18 & 17 & & & \\
\hline 2 & Мінімальне значення, мБк/с м² & 8 & 121 & 24 & 51,00 & $-84 \%$ & $137 \%$ & $-53 \%$ \\
\hline 3 & Максимальне значення, мБк/с м² & 375 & 637 & 713 & 575,00 & $-35 \%$ & $11 \%$ & $24 \%$ \\
\hline 4 & Середнє значення (А), мБк/с м² & 63,29 & 336,38 & 332,33 & 244,00 & $-74 \%$ & $38 \%$ & $36 \%$ \\
\hline 5 & $\begin{array}{l}\text { Кратність перевищення макс. I мін. } \\
\text { значень, рази }\end{array}$ & 46,88 & 5,26 & 29,71 & 27,28 & $72 \%$ & $-81 \%$ & $9 \%$ \\
\hline 6 & Медіана (М), мБк/с м² & 32 & 303 & 311 & 215,33 & $-85 \%$ & $41 \%$ & $44 \%$ \\
\hline 7 & $\begin{array}{l}\text { Відхилення медіани від середнього } \\
\text { (А-М)/А, \% }\end{array}$ & $49 \%$ & $10 \%$ & $6 \%$ & $22 \%$ & $125 \%$ & $-55 \%$ & $-71 \%$ \\
\hline
\end{tabular}

Таблиця 2. Результати вимірювання ЩПР на території Новокостянтинівського родовища урану у 2018 році, мБк/с м² Table 2. Results of radon flow measurements on the territory of Novokostiantynivske uranium deposit in $2018, \mathrm{mBq} / \mathrm{sec} \mathrm{m}^{2}$

\begin{tabular}{|r|c|c|r|r|r|r|r|r|r|r|r|r|}
\hline $\mathrm{N}$ & $\mathrm{X}$ & $\mathrm{Y}$ & ЩПР & \multicolumn{1}{|c|}{$\mathrm{N}$} & $\mathrm{X}$ & $\mathrm{Y}$ & ЩПР & $\mathrm{N}$ & $\mathrm{X}$ & $\mathrm{Y}$ & ЩПР \\
\hline 1 & 31,732434 & 48,576613 & 180 & 7 & 31,733627 & 48,584357 & 599 & 13 & 31,728428 & 48,584442 & 635 \\
\hline 2 & 31,735419 & 48,576368 & 452 & 8 & 31,743924 & 48,577912 & 188 & 14 & 31,732641 & 48,593539 & 243 \\
\hline 3 & 31,720015 & 48,582653 & 502 & 9 & 31,743755 & 48,580058 & 314 & 15 & 31,733013 & 48,598765 & 316 \\
\hline 4 & 31,730966 & 48,583078 & 465 & 10 & 31,744811 & 48,583101 & 369 & 16 & 31,735695 & 48,601253 & 308 \\
\hline 5 & 31,738892 & 48,581169 & 24 & 11 & 31,744538 & 48,587905 & 158 & 17 & 31,738368 & 48,603227 & 149 \\
\hline 6 & 31,724644 & 48,581557 & 289 & 12 & 31,743993 & 48,595349 & 78 & 18 & 31,743281 & 48,601115 & 713 \\
\hline
\end{tabular}

Для просторового відображення результатів досліджень виконується комп'ютерне картування результатів на програмному комплексі ArcMap. Для коректного визначення полів розподілу «фонових» та аномальних показників перш за все необхідне виявлення аномальних зон радіаційних забруднень на досліджуваній території. Отже, для побудови карт розподілу показників необхідно встановити градацію шкали граничних значень (визначити «мітки» шкали).

Як видно з табл. 2, у ряді результатів вимірювань присутні аномально високі результати, які виключаються при визначенні усереднених, «фонових», показників. Це показники, що удвічі і більше перевищують середнє значення ряду - 332 мБк/с м². Таким чином, у ряді без аномальних показників отримуємо середнє значення ЩПР, яке складає 204 мБк/с м² (мітка шкали № 1). Максимальна апаратурна похибка вимірювання ЩПР складає до 30\%; для встановлення межі перевищення рівня «фону» необхідно додати до середнього значення величину подвійної похибки; в результаті отримуємо граничний показник 326 мБк/с $\mathrm{M}^{2}$ (мітка № 2). Це показник шкали, який показує наявність перевищення «фону». Наступне граничне значення - середнє значення аномальних показників 533 мБк/с м² (мітка № 3). Остання мітка № 4 - другий за величиною виміряний результат ЩПР - 635 мБк/с м². Для зручності сприйняття значення міток округлені до десятків; у нижній частині шкали доцільно додати проміжні показники - 80 та 160 мБк/с м².

На рисунку 4 показано розподіл виміряних показників за величиною ЩПР за вищенаведеними мітками шкали.

На рисунку 5 показано отриману карту полів розподілу виміряних показників ЩПР. 


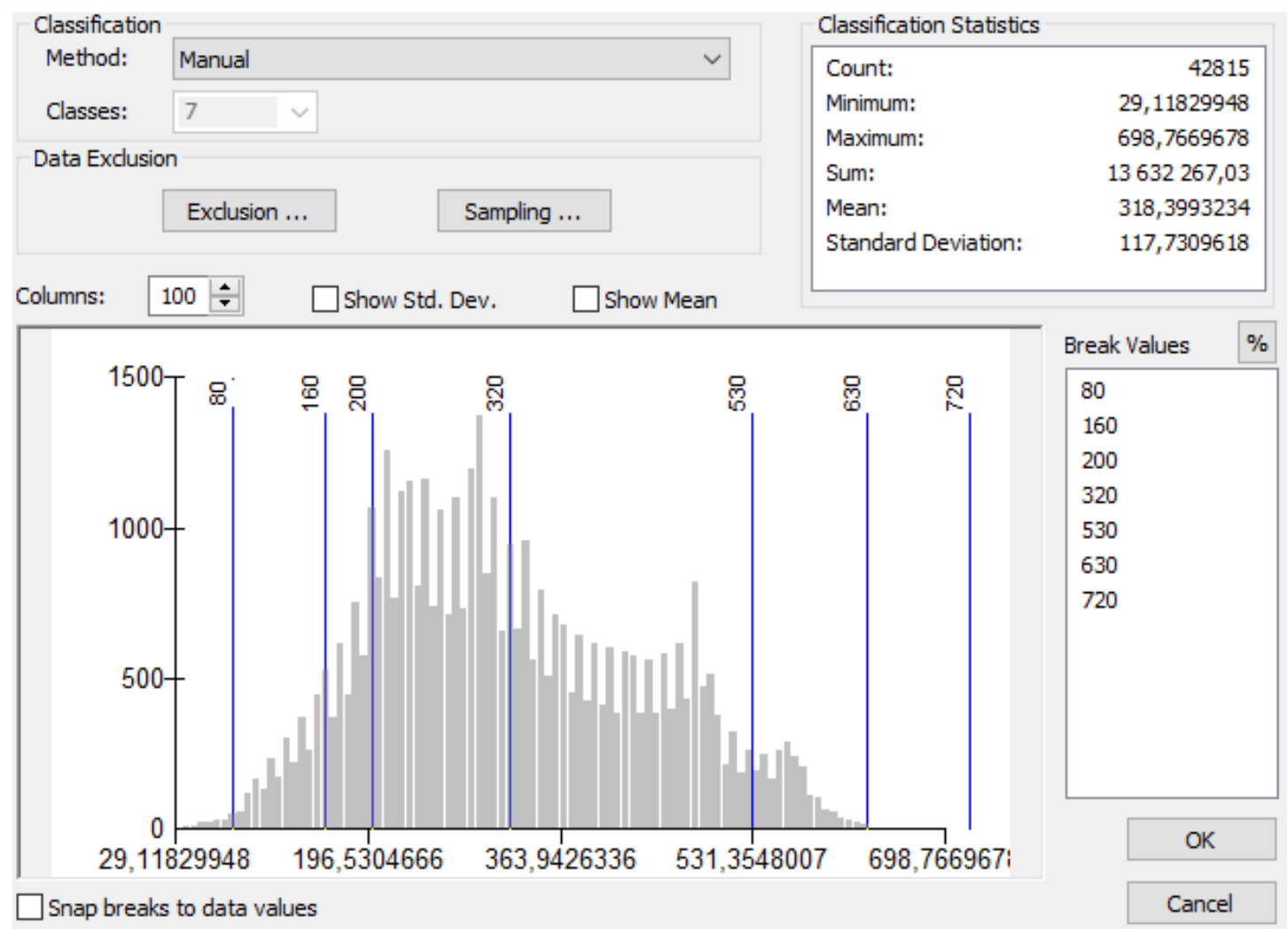

Рис. 4. Розподіл вимірів ЩПР за визначеними граничними показниками у меню ArcMap

Fig. 4. Distribution of radon flow measurements according to the defined limits in the ArcMap menu
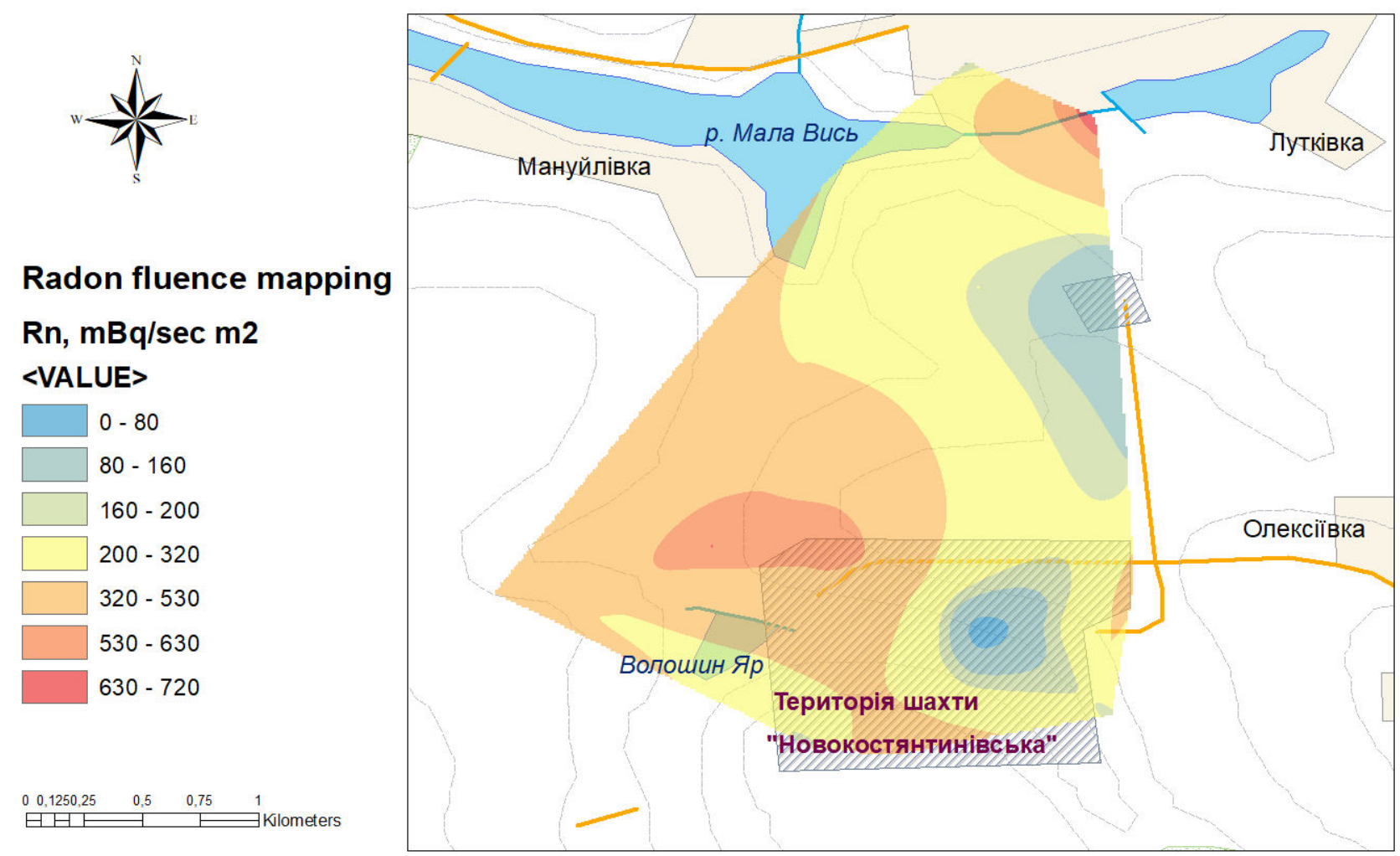

Рис. 5. Карта полів розподілу показників ЩПР, виміряних на території Новокостянтинівського родовища урану у 2018 році

Fig. 5. The map of the radon flow distribution fields measured on the territory of Novokostiantynivske uranium deposit in 2018 
На карті, представленій на рисунку 5, блакитним та жовтим кольорами позначено поля розподілу «фонових» показників, помаранчевим і червоним поля розподілу показників, які перевищують «фонові» значення. Найбільше перевищення «фону» локалізоване у північно-західній частині території шахти, інше - у руслі р. Мала Вись.

Для порівняння на рисунку 6 показано карту, побудовану аналогічним методом за показниками, виміряними у 2017 p.
Як бачимо, просторова конфігурація полів розподілу аномальних показників, виміряних у 2018 та 2017 роках, досить близька.

Наведемо також приклад обробки результатів, отриманих для іншого показника, наприклад, потужності еквівалентної дози (ПЕД) гаммавипромінювання, виміряної на висоті 1 м від поверхні грунту у 2017 і 2018 роках (рисунки 7 та 8).
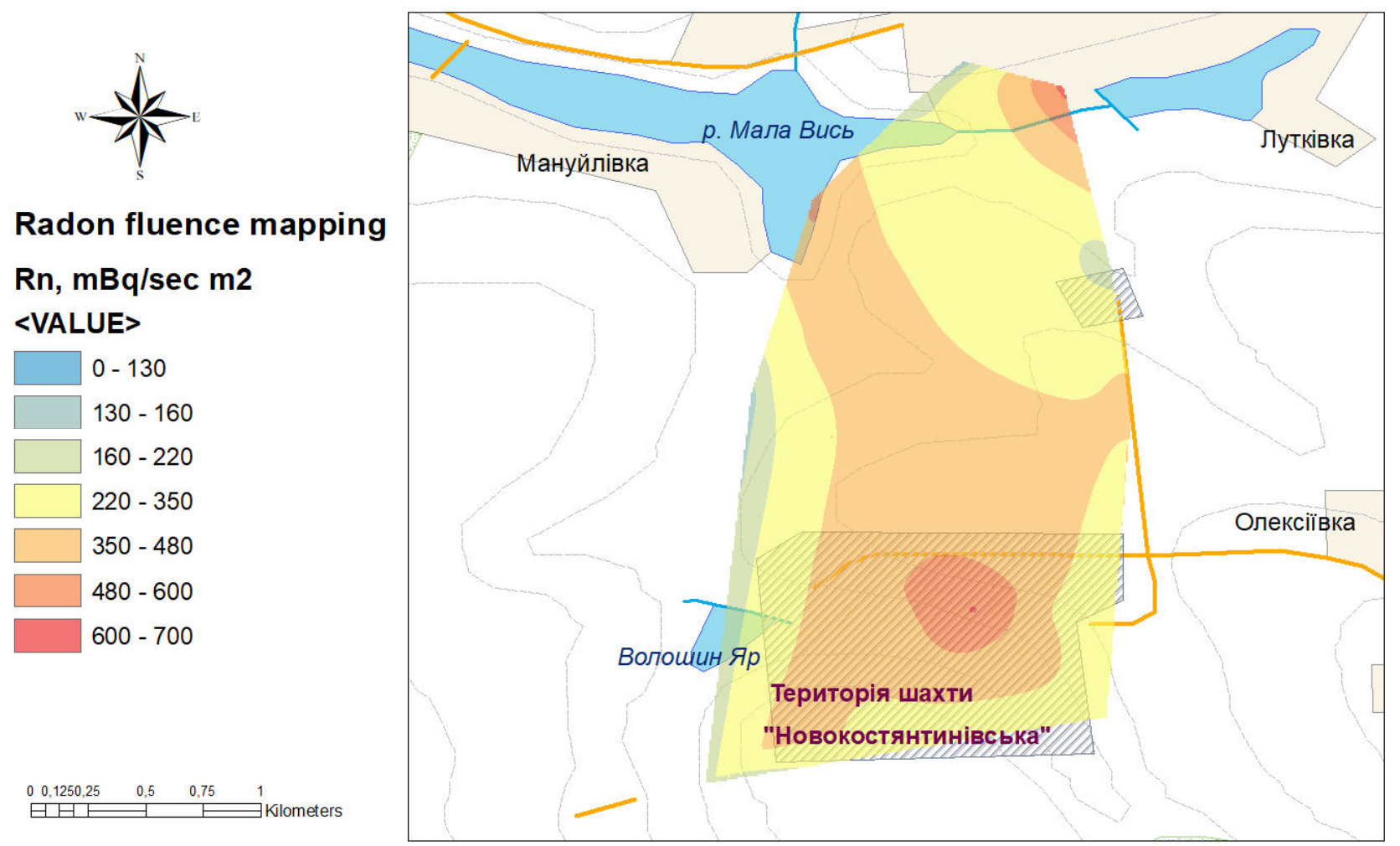

Рис. 6. Карта полів розподілу показників ЩПР, виміряних на території Новокостянтинівського родовища урану у 2017 році Fig. 6. The map of the radon flow distribution fields measured on the territory of Novokostiantynivske uranium deposit in 2017

На рисунках 7 та 8 бузковим кольором показано поля розподілу ПЕД, показники яких надійно перевищують «фонові», а рожевим - значно перевищують.

Характер розподілу аномальних показників ПЕД показує значне забруднення території шахти та прилеглих земель, що вказує на опосередкований (техногенний) вплив діяльності підприємства на формування еквівалентної дози.

Аналіз інших радіаційних показників на території Новокостянтинівського родовища, виміряних під час польових та камеральних робіт, також підтверджує можливість визначення і картування аномальних зон полів розподілу радіаційного забруднення, які перевищують «фонові» показники.

Висновок: описаний метод дозволяє надійно визначати аномальні зони розподілу радіологічних показників на досліджуваній території та показати їх просторове поширення шляхом комп'ютерного картування. Отримані результати можуть бути використані як для характеристики радіоекологічної ситуації, так і в якості пошукового критерію, як під час проведення вишукувань на територіях родовищ урану, так $\mathrm{i}$ на будь-яких інших територіях. 


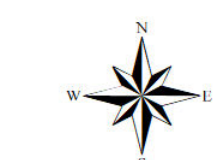

Equal dose rate mapping $\mathrm{mcSv} / \mathrm{h}$

<VALUE>

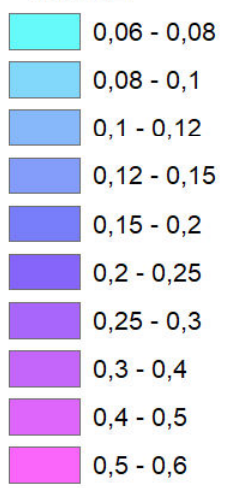

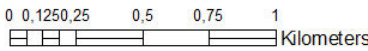

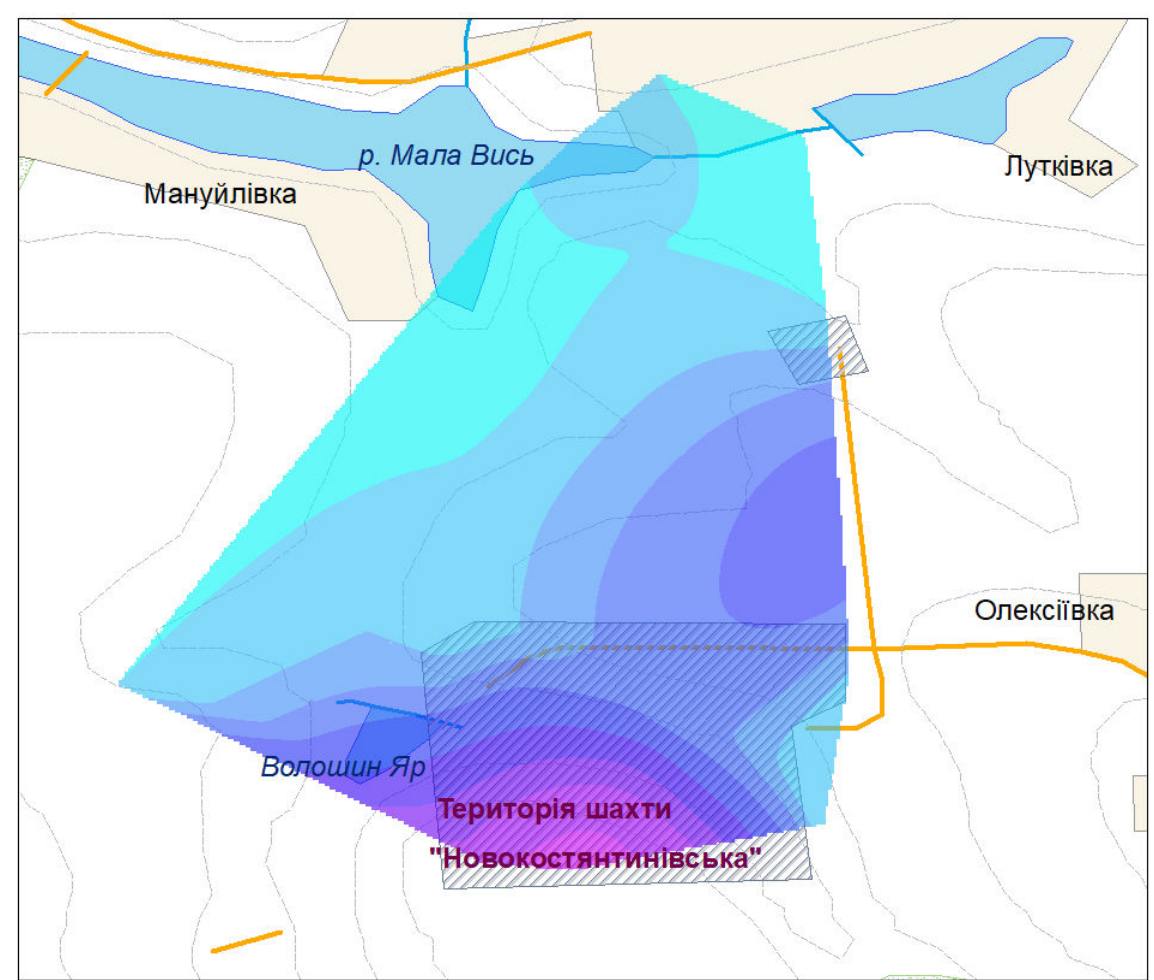

Рис. 7. Карта полів розподілу показників ПЕД, виміряних на території Новокостянтинівського родовища урану у 2018 році Fig. 7. The map of the equivalent dose rate distribution fields measured on the territory of Novokostiantynivske uranium deposit in 2018
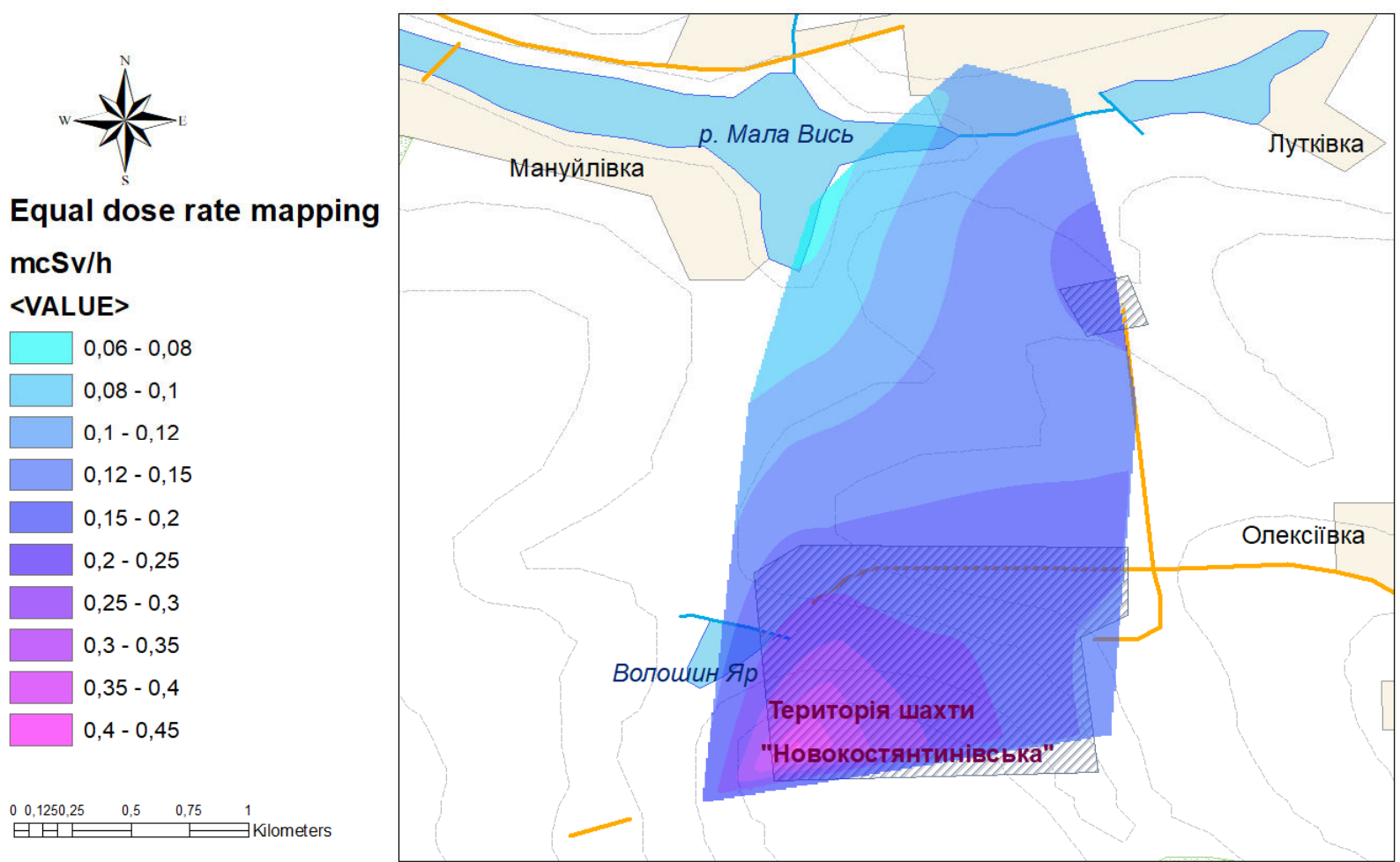

Рис. 8. Карта полів розподілу показників ПЕД, виміряних на території Новокостянтинівського родовища урану у 2017 році

Fig. 8. The map of the equivalent dose rate distribution fields measured on the territory of Novokostiantynivske uranium deposit in 2017 


\section{Література}

1. Перспективи розвитку уранової сировинної бази ядерної енергетики України / Відп. Ред. Верховцев В.Г., Лисиченко Г.В.- Київ: Наук. думка, 2014. - 355 с.

2. Перспективи розвитку торієвої сировинної бази ядерної енергетики України / Відп. 25асс. Верховцев В.Г., Ярощук М.А. - Київ: Наук. думка, 2017. - 269 с.

3. Белевцев Я.Н. Метаморфогенное рудообразование. Москва: Недра, 1979. - 275 с.

4. Белевцев Я.Н., Бакаржиев А.Х., Коваль В.Б. и др. Урановые месторождения Украины // Геол. Журн. 1992. № 5. С. $28-44$.

5. Генетические типы и закономерности размещения урановых месторождений Украины / Отв. ред. Белевцев Я.Н., Коваль В.Б. - Киев: Наук. думка. 1995. 397 с.

6. Верховцев В.Г. та 25ac. Комплексна оцінка та геолого-економічне обгрунтування перспектив освоєння екзогенних родовищ урану осадового чохла Українського щита. Звіт про науково-дослідну роботу. Етап 1. Історія формування осадового чохла Українського щита та епохи уранонакопичення в екзогенних умовах. УДК 550.4:574.3. - Київ, ДУ «ГГНС НАН України», 2016. 133 с.

7. Cuney M., Shcherbak M.P., Emetz A.V., Petrychenko K.V., Sinelu S. Petrological and Geochronological Peculiarities of Novoukrainka Massif Rocks and Age Problem of Uranium Mineralization of the Kirovograd Megablock of the Ukrainian Shield // Мінерал. журн. 2008. 30, №2. С. 5-16.

8. Степанюк Л.М., Андрієнко О.М., Довбуш Т.І., Бондаренко В.К. Вік формування порід Новоукраїнського 25ассиву // Мінерал. журн. - 2005. - 27, № 1. - С. 44-50.

9. Верховцев В.Г. Прикладные (поисковые и инженерно-геологические) аспекты изучения платформенных геоструктур Украины // Екологія довкілля та безпека життєдіяльності. 2005. № 3. С. 80-92.

\section{References}

1. Perspektyvy rozvytku uranovoji syrovynnoji bazy jadernoji energetyky Ukrajiny / Vidp. Red. Verkhovtzev V.G. and Lysychenko G.V. (2014), Nauk. Dumka, Kyiv, UA, 355 p.

2. Perspektyvy rozvytku torijevoji syrovynnoji bazy jadernoji energetyky Ukrajiny / Vidp. Red. Verkhovtzev V.G. and Jaroshchuk M.A. (2016), Nauk. Dumka, Kyiv, UA, 269 p.

3. Bielivtzev, J.N. (1979) Metamorfogennoie rudoobrazovanije. Nedra, Moskva. 275 p.

4. Bielivtzev J.N., Bakarjiev A.Ch., Koval' V.B. (1992) Uranovyje miestorojdenija Ukrainy, Geol. Zhurn, N 5, pp. $28-44$

5. Geneticheskije tipy $i$ zakonomernost razmieshchenija uranovyh miestorozhdienij Ukrainy / Otv. Red. Bielivtzev, J.N., Koval', V.B. (1995), Nauk. Dumka, Kyiv, UA, $397 \mathrm{p}$.

6. Komplexna otsinka ta geologo-ekonomichne obgruntuvannia perspektyv osvojennia exogennych rodovyshch uranu osadovogo chohla Ukrajins`kogo shchyta. UDK 550.4:574.3. Verchovtsev ta in. (2016). Kyiv, UA, 133 p.

7. Cuney M., Shcherbak M.P., Emetz A.V., Petrychenko K.V., Sinelu S. (2008) Petrological and Geochronological Peculiarities of Novoukrainka Massif Rocks and Age Problem of Uranium Mineralization of the Kirovograd Megablock of the Ukrainian Shield // Min. Zhurn. 30, № 2. p. 5-16.

8. Stepaniuk L.M., Andrijenko O.M., Dovbush T.I., Bondarenko V.K. (2005) Vik formuvannia pored Novoukrajins'kogo masyvu. Min. Zhurn. 27, № 1. p. 44-50.

9. Verkhovtsev V.G. (2005), Prykladnye (poyskovye y ynzhenerno-heolohycheskye) aspekty izuchenyya platformennykh geostruktur Ukrainy, Ekologiya dovkillya ta bezpeka zhyttyediyalnosti № 3, RU, pp. 80-92.

\section{THE METHOD OF SPATIAL MAPPING OF THE DISTRIBUTION FIELDS OF RADIATION RATES ON THE EXAMPLE OF THE MEASURING DATA PROCESSING FOR THE NOVOKOSTIANTYNIVKA URANIUM DEPOSIT AREA}

Tyshchenko Yu. E. Ph.D. (Geol.), SE "IGE NAS of Ukraine", u-risk@ukr.net

The article is devoted to the optimization of the procedure of processing and interpretation of information obtained during radiological measurements of environmental components. Analytical processing of the data arrays is accompanied by their spatial mapping using computer mapping tools. The effectiveness of such presentation depends on the reliability of the choice of criteria for which the spatial fields of the allocation of measured indicators are built. The article proposes approaches to the spatial mapping of the results of specific radioecological monitoring studies, which are performed annually by the Institute of Geochemistry of the Environment of the National Academy of Sciences of Ukraine. On the example of processing of the actual data obtained during field works on the Novokostiantynivka uranium deposit area, a method of ranking the series of measured indicators is presented, which takes into account the apparatus error when taking instrumental measurements. The information processing method is illustrated by the results of constructing maps of the spatial distribution of the measured radon flow density data from soil obtained during the recent field work. The fields of distribution of "background" and abnormally high measured indicators are mapped. The latter coincide in space with the uranium deposit location. Also, their presence in the places of occurrence of geological fault structures and probable zones of decomposition of the sedimentary layer is traced. The results of spatial mapping are compared with similar results the actual data mapping of the preceding year of research and results of mapping of another indicator of radiological measurements - the equivalent gamma radiation dose rate in the environment. The obtained results show that the described method can be used for reliable detection of abnormal pollution zones in the investigated area and their spatial mapping. The mapping of abnormal zones can be used in assessing the radioecological situation in radiation-polluted areas, in particularuranium deposits, as well as the indirect search criterion for remote research. Also the article presents a brief geological description of the Novokostiantynivske uranium deposit, its geological map, plan and sections.

Key words: uranium, deposit, radon, radiation, distribution fields, mapping 